\title{
Detection of Brucella Antibodies of Sheep in Al-Anbar Province by Using Some Serological Tests
}

\author{
Ahmed H. Al-Tae and Ekram A. Al-Samarrae \\ Department of Microbiology, College of Veterinary Medicine, University of Baghdad, Baghdad, Iraq \\ dr.ekramabbas40@yahoo.com \\ Accepted on 30/9/2012 \\ Summary
}

An investigation was carried out to detect anti-Brucella antibodies of sheep in Al-Anbar province by using few serological tests; rose Bengal plate test (RBPT) and tube agglutination test (TAT). A total of 754 sheep blood samples (94 Ram and 660 Ewe) were collected randomly distributed in Al-Anbar province from unvaccinated sheep flocks with different ages. A total percentage of infected sheep depending on RBPT was $10.21 \%$ with significant differences at $(\mathrm{P}<$ 0.01 ), it was $9.69 \%$ in ewes, whereas in rams it elevated to reach $13.82 \%$, in addition to the disease was higher seroprevalence at $>3$ years $(12.78 \%)$ in both gender with significant differences at $(\mathrm{P}<0.05)$ than lower ages. Out of 77 RBPT positive sera, 38(49.35\%) were positive using TAT, there was 14 seropositive with significant differences at $(\mathrm{P}<0.01)$. The study reported that brucellosis was distributed in Al-Anbar province with variable percent (3.26\% to $21.27 \%$ ), as well as emphasized on different epidemiological aspects.

Keywords: Brucella, Sheep, Al-Anbar, Rose Bengal, Tube agglutination.

\section{Introduction}

Brucellosis is one of the most common zoonotic diseases worldwide (1) which affect both humans and various species of domesticated and wild animals (2). Brucellosis in domestic animals, particularly in sheep is a chronic infectious disease (3). Therefore, ovine brucellosis has important effects for both human health and animal reproduction (4). It remains a major source of disease in humans and domesticated animals worldwide. Although incidence and prevalence of the disease vary widely from country to country, bovine brucellosis caused mainly by Brucella abortus is still the most widespread form. In humans, ovine and caprine brucellosis caused by Brucella melitensis is the most important clinically apparent disease (5).

Serological tests are widely used to detect specific Brucella antibody in sera and other body fluids by a variety of techniques. RBPT has been accepted as efficient for use in human and all animal species. This test is a simple, rapid and an excellent test for the large-scale screening of sera. False positive and false negative can occur. However, the
RBPT has specifity and high sensitivity (6 and 7). Although TAT was used extensively for brucellosis diagnosis; simple and cheap to perform with a standardized antigen preparation, and titers which can be expressed in international units (IU) can be correlated well with clinical stages of infection (8). Diagnosis of clinical brucellosis in humans and animals is initially made by use of appropriate serological or other immunological tests, and confirmed by bacteriological isolation and identification of the agent (9). So, there are many serological tests such as rose Bengal plate test (10), tube agglutination test (11), 2-mercaptoethanol (12), competitive - enzyme linked immunosorbent assay (13), indirect - enzyme linked immunosorbent assay immunoglobulin class $M$ and immunoglobulin class $G$ (14) to diagnose brucellosis in ruminants (sheep, goats and cattle) and humans. Therefore, it designated this study in Al-Anbar province to diagnose sheep brucellosis by RBPT and TAT.

\section{Materials and Methods}

A total 754 of Sheep blood samples (94 from Rams and 660 from Ewes) were 
collected randomly and treated from unvaccinated sheep flocks suffering from abortion or not, with different ages for the period from December $/ 2010$ to September /2011. These samples collected from different districts in Al-Anbar province which include: Ramadi, Fallujah, Hit, Hadithah, Ana, Rawa, Qaim and Rutba. Serum was separated by centrifugation at 3000 r.p.m. /15 minute (15). Rose Bengal Plate Test was used OIE (16). Tube Agglutination Test applied according to Alton (15). Data were collected and statistically analyzed by using SPSS program (17).

\section{Results and Discussion}

Rate of infection of sheep brucellosis by using rose bengal plate test (RBPT) according to areas of study, 754 sheep sera samples tested, $77(10.21 \%)$ were positive with RBPT of eight administrative regions in Al-Anbar province. Higher seroprevalence 20(21.27\%) was found in Rutba district with significant differences at $(\mathrm{P}<0.01)$ than the lower seroprevalence $3(3.26 \%)$ recorded in Rawa district (Table, 1).

Table, 1: Rate of infection of sheep brucellosis by using RBPT according to areas of study

\begin{tabular}{|llll|}
\hline Districts & $\begin{array}{l}\text { No. of Positive } \\
\text { sera } \\
\text { tested }\end{array}$ & $\begin{array}{l}\text { Percentage } \\
(\%)\end{array}$ \\
\hline Rutba & 94 & 20 & $21.27 *$ \\
\hline Fallujah & 97 & 14 & 14.43 \\
\hline Ramadi & 97 & 12 & 12.37 \\
\hline Hit & 96 & 10 & $\mathbf{1 0 . 4 1}$ \\
\hline Hadithah & $\mathbf{9 3}$ & $\mathbf{7}$ & $\mathbf{7 . 5 2}$ \\
\hline Qaim & $\mathbf{9 3}$ & $\mathbf{7}$ & $\mathbf{7 . 5 2}$ \\
\hline Ana & 92 & 4 & $\mathbf{4 . 3 4}$ \\
\hline Rawa & $\mathbf{9 2}$ & $\mathbf{3}$ & $\mathbf{3 . 2 6}$ \\
\hline Total no. & $\mathbf{7 5 4}$ & $\mathbf{7 7}$ & $\mathbf{1 0 . 2 1}$ \\
\hline
\end{tabular}

$*(\mathbf{P}<\mathbf{0 . 0 1})$

The main serological test used for diagnosis of brucellosis is RBPT, which is use as a useful screening test (18), it is simple and rapid, although, it is known to have many false positive and few false negative, but generally, it is an excellent screening method (16). On the other hand, it detects IgG1 and IgM due to antigens buffered at $\mathrm{pH} 3.65-4.0$ (acid conditions) allows IgG1 to cause agglutination (19 and 20).
The seroprevalence of brucellosis in sheep was widely but unevenly distributed throughout flocks and province (21). This mean, there is a positive association among population density (number of animals to land area), grazing strategy and disease prevalence (Brucella seroprevalence), which is attributed to increased opportunity for animals to come in contact with potentially infected flocks during their movements and co-mingling (22). Rutba district is higher Brucella seroprevalence than other administrative regions in the study area it may be due to area, grazing strategy and population density.

The results disagreed with other studies (23, 24 and 25); in Baghdad; in addition to Dhahir (26) in Baghdad, Salah-Eldin and Dyala provinces; Saleem (27); Al-Abdaly (28); AlHangawe (29); Al-Farwachi (30) and Arslan (31) in Ninevah province and in a percentage of $7.9 \% ; 23.3 \% ; 15 \% ; 53.5 \% ; 13.3 \% ; 6.74 \%$; $11.8 \%$; $66.7 \%$ and $8.77 \%$, respectively. when comparison with the previous studies, it was found that the seroprevalence of sheep brucellosis alterated throughout the last twenty seven years due to owner's ignorance with the hazards of the disease (32), unhygienic disposal of infected animals as well as aborted fetuses or placental membranes (6), uncontrolled rigid restriction of the movement of diseased animals, the bad management and nutritional deficiencies (32).

In present results; the percent of infection are differ from previous studies due to the number of animals tested and geographical variabilities $(24,25,26,27,28,29,30$ and 31 ), or due to the state of animals (pregnant, aborted or apparently healthy) (23). The rate of brucellosis infection in sheep by using RBPT according to gender: Results of this study revealed differences in the infection rates of sheep brucellosis according to gender. Ninety four rams sera tested, 13 (13.82\%) were positive, while on the contrary, 660 ewes sera tested, $64(9.69 \%)$ were positive with RBPT (Table,2). The results showed higher percentage in rams in comparison with ewes to be preferable to insertion a few numbers of rams to fixed large numbers of ewes during 
management of natural breeding, will raise the percentage of infection.

Table, 2: Rate of infection of sheep brucellosis by using RBPT according to gender

\begin{tabular}{|cccc|}
\hline Gender & $\begin{array}{c}\text { No. of sera } \\
\text { tested }\end{array}$ & Positive & $\begin{array}{c}\text { Percentage } \\
(\%)\end{array}$ \\
\hline Rams & $\mathbf{9 4}$ & $\mathbf{1 3}$ & $\mathbf{1 3 . 8 2}$ \\
\hline Ewes & $\mathbf{6 6 0}$ & $\mathbf{6 4}$ & $\mathbf{9 . 6 9}$ \\
\hline \hline Total & $\mathbf{7 5 4}$ & $\mathbf{7 7}$ & $\mathbf{1 0 . 2 1}$ \\
\hline
\end{tabular}

This result is agreed with (28), who referred that the seroprevalence rates of rams were higher than ewes; $7.4 \%$ and $6.5 \%$, respectively. Also, (29) recorded that infection in rams was higher than ewes $12.1 \%$ and $11.7 \%$, respectively. And (33) who stated the prevalence in rams were much higher than ewes $50 \%$ and $36.5 \%$, respectively; on other hand (27) referred that the seroprevalence rates of rams were much higher than ewes $65.6 \%$ and $10.6 \%$, respectively. This result is disagreed with Mansour (34) who mentioned that brucellosis infection rates of rams were less than ewes $1.4 \%$ and $5.7 \%$, respectively. Rate of infection of sheep brucellosis by using RBPT according to age group: Among the prevalence of sheep brucellosis according to age group, it was found that the high seroprevalence rate $(12.78 \%)$ was at more than 3 years old, with significant differences at $(\mathrm{P}<0.05)$ than the low seroprevalence rate $(0.0 \%)$ which was recorded at lesser than 1 year old (Table, 3 ).

Table, 3: Rate of infection of sheep brucellosis by using RBPT according to age group

\begin{tabular}{|cccccc|}
\hline $\begin{array}{c}\text { Age } \\
\text { group } \\
\text { (year) }\end{array}$ & $\begin{array}{c}\text { No. of } \\
\text { sera } \\
\text { tested }\end{array}$ & $\begin{array}{c}\text { No. of sheep seropositive } \\
\text { for RBPT }\end{array}$ & Rams & Ewes & Sum \\
Percent \\
age $(\%)$
\end{tabular}

The high seroprevalence rate was at $>3$ years age group, as a result of the fact that it is the breeding age for ewes and rams (35); or it may be attributed to the increasing animals' exposure to Brucella microorganism (32), or to both reasons (36). On the other hand, the low seroprevalence rate was at $<1$ year age group because of absence of infection (true negative) (37) or it may be attributed to latent or in-apparent infections can occur in all farm animal species. Sexual mature animals are more prone to the infection than sexual immature animals of both sexes (6). This is related to the fact that sex hormones and erythritol in males (testicles and seminal vesicles) and erythritol in females allantoic fluid stimulate the growth and multiplication of Brucella organisms and tend to increase concentration with age and sexual maturity (38). The results of the current study is agreed with Saleem (27) that the high seroprevalence rate at $>3$ years, and were disagreed with Mustafa (33) who reported that the high seroprevalence rate at 2-3 years, may be due to the difference in the age groups that were studied.

Brucella infection rate by using tube agglutination test (TAT) revealed that out of 77 RBPT positive sera, 38 (49.35\%) were positive using TAT, at the titer varying between 40 to 1280 , with most frequent titers were between 40-160. There was 14 seropositive out of 77 and with significant differences at $(\mathrm{P}<0.01)$. While the $10 \mathrm{RBPT}$ negative sera, considered negative $(100 \%)$ and the serum with agglutination at a dilution 1:40 (titer of 40) and above was recorded as positive sample according to manufactured company of antigen (Table,4).

Table, 4: Rate of infection of sheep brucellosis by using TAT for positive and negative sera with RBPT

\begin{tabular}{|c|c|c|c|c|c|c|c|c|c|}
\hline \multirow[t]{2}{*}{ Samples } & \multicolumn{9}{|c|}{ Antibody titer for TAT } \\
\hline & 10 & 20 & 40 & 80 & 160 & 320 & 640 & 1280 & $\begin{array}{c}\text { Total } \\
\text { positive } \\
\text { sera }\end{array}$ \\
\hline $\begin{array}{c}\text { Positive } \\
\text { sera for } \\
\text { RBPT } \\
(77 \\
\text { samples) }\end{array}$ & 9 & 12 & $* 14$ & 9 & 10 & 2 & 2 & 1 & 38 \\
\hline $\begin{array}{c}\text { Negative } \\
\text { sera for } \\
\text { RBPT } \\
(10 \\
\text { samples })\end{array}$ & 2 & 1 & $\mathbf{0}$ & $\mathbf{0}$ & $\mathbf{0}$ & $\mathbf{0}$ & $\mathbf{0}$ & $\mathbf{0}$ & $\mathbf{0}$ \\
\hline
\end{tabular}

The TAT is one of the traditional standard tests which are widely used (6), and it is recommended for collection of quantitative 
information of immune responses. It is the most frequently used confirmatory serological test (18). This test is detecting most antibodies in the serum (IgM, IgG1 and IgG2) (19). The degree of agreement between RBPT and TAT was $49.35 \%$ for positive sera with RBPT in this study.

The differences in both tests might due to that the animals were at the incubation period of disease, after abortion or during the chronic stage of disease which the serum agglutinin tend to wane, often becoming negative when the results of some other tests may be positive (6). Also, antibodies of the IgG1 produced in some sera, at least, have the capacity to block agglutination by other immunoglobulin, particularly $\operatorname{IgM}$; therefore, IgG1 antibodies fail to agglutinate while $\operatorname{IgM}$ is far the most efficient $(19,20)$. This interpretation confirmed by our results which obtained in this study that may be referred the positive results for TAT due to the acute stage of this disease.

The results are agreed with Al-Abdaly (28) and Al-Hangawe (29), who referred that the most frequent titers are between 40-160, in the

\section{References}

1. Hegazy, Y.M.; Moawad, A.; Osman, R.; Ridler, A. and Guitian, J. (2011). Ruminant brucellosis in the Kafr El Sheikh Governorate of the Nile Delta, Egypt: Prevalence of a Neglected Zoonosis. PLoS. Negl. Trop. Dis., 5(1): 944-954.

2. Sathyanarayan, M.S.; Suresh, D.; Suresh, B.S.; Krishna, S.; Mariraj, J.; Surekha, Y.; Ravichandra, P. and Ravikumar, R. (2011). A comparative study of agglutination tests, blood culture and ELISA in the laboratory diagnosis of human brucellosis. Int. J. Biol. Med. Res., 2(2): 569-572.

3. Megid, J.; Mathias, L.A. and Robles, C.A. (2010). Clinical manifestations of brucellosis in domestic animals and humans. Vet. Sci. J., 4:119-126.

4. Sulima, M. and Venkataraman, K.S. (2010). Economic losses associated with brucellosis of sheep and goats in Tamil nadu. Tamil Nadu J. Vet. Anim. Sci., 6(4): 191-192. early or late stage of infection that associated with $\operatorname{IgG}$ and $\operatorname{IgM}$ (39). The appearance of low antibody titers (10 and 20) may be due to decline antibodies after animal recovery from the disease and the agglutination occured due to residual immunoglobulins, especially $\mathrm{IgG}$ which persist for several months, or for one year (37); but disagreed with the others by researchers $(23,24,27,28,29$ and 33) which found percentages $83.33 \% ; 70.7 \% ; 100 \%$; $65 \% ; 55.8 \%$ and $90.7 \%$, respectively.

The discrepancies in the results may be due to the time of the study (seasonal variation), number of samples which taken, stage of the disease and sensitivity of the tests which lead to false positive or negative results (40). In conclusion the brucellosis was distributed in Al-Anbar province, especially in Rutba than other districts. Also, the infection rate of brucellosis was high in rams than ewes, in addition to the disease was higher seroprevalence in advancing age ( $>3$ years in both gender than lower age). Finally, RBPT is highly sensitive than TAT for detection of anti-Brucella antibodies.

5. Corbel, M.J. (1997). Brucellosis: an Overview. International Conference on Emerging Zoonoses. Emerg. Infect. Dis., 3(2): 1-13.

6. Radostits, O.M.; Gay, C.C.; Hinchcliff, K.W. and Constable, P.D. (2007). Veterinary Medicine: A textbook of the diseases of cattle, horses, sheep, pigs and goats. $10^{\text {th }}$ ed. Elsevier Saunders, London, PP: 966-994.

7. Gomez, M.C.; Nieto, J.A.; Rosa, C.; Geijo, P.; Escribano, M.A.; Munoz, A. and Lopez, C. (2008). Evaluation of seven tests for diagnosis of human brucellosis in an area where the disease is endemic. Clin. Vaccine Immunol., A.S.M. J., 15(6): 1031-1033

8. FAO/ OIE/ WHO (2006). Brucellosis in humans and animals. World Health Organization Press, 20 Avenue Appia, 1211 Geneva 27, Switzerland.

9. Robinson, A. (2003). Guidelines for coordinated human and animal brucellosis 
surveillance. animal production and health paper 156. Food and Agriculture Organization (FAO) of the United Nations, Rome.

10. Ferede, Y.; Mengesha, D.; Mekonen, G. and Hmelekot, M. (2011). Study on the seroprevalence of small ruminant brucellosis in and around Bahir Dar, North West Ethiopia. Ethiop. Vet. J., 15(2): 3544.

11. Rahman, M.S.; Faruk, M.O.; Her, M.; Kim, J.Y.; Kang, S.I. and Jung, S.C. (2011). Prevalence of brucellosis in ruminants in Bangladesh. Vet. Med., 56(8): 379-385.

12. Akbarmehr, J. and Ghiyamirad, M. (2011). Serological survey of brucellosis in livestock animals in Sarab City (East Azarbayjan province), Iran. African J. Microbiol. Res.; 5(10): 1220 - 1223.

13. Portanti, O.; Tittarelli, M.; Di, F.T.; Luciani, M.; Mercante, M.T.; Conte, A. and Lelli, R. (2006). Development and validation of a competitive ELISA kit for the serological diagnosis of ovine, caprine and bovine brucellosis. J. Vet. Med. B. Infect. Dis. Vet. Public Health, 53(10): 494-498.

14. Pabuccuoglu, O.; Ecemis, T.; El, S.; Coskun, A.; Akcali, S. and Sanlidag, T. (2011). Evaluation of Serological Tests for Diagnosis of Brucellosis. Japanese $\mathrm{J}$. Infect. Dis.; 64: 272-276.

15. Alton, G.G.; Jones, L.M.; Angus, R.D. and Verger, J.M. (1988). Techniques for the Brucellosis Laboratory. Paris: INRA.

16. OIE (Office International des Epizooties) (2004). Bovine brucellosis. World Organization for Animal Health. In: OIE manual of diagnostic tests and vaccines for terrestrial animals. Paris: OIE., http://www.oie.int/ .

17. SPSS (2008). Statistical Package for the Social Sciences, Version 16 and 17 (Win/Mac/Linux), User's guide SPSS Inc., Chicago III, USA., http://www.spss.com .

18. Gul, S.T. and Khan, A. (2007). Epidemiology and Epizotology of Brucellosis: a Review. Pakistan. Vet. J., 27(3): 145-151.

19. Joint FAO/WHO Expert Committee on Brucellosis (1986). World Health
Organization Technical Report. Series. 740 Sixth Report. Geneva, Switzerland.

20. Quinn, P.J.; Carter, M.E.; Markey, B. and Cater, G.R. (2004). Clinical Veterinary Microbiology. Elsevier Limited, www.elsevierhealth.com.

21. Kaoud, H.A.; Zaki, M.M.; El-Dahshan, A.R. and Nasr, S.A. (2010). Epidemiology of Brucellosis among Farm Animals. Nat. and Sci., 8(5):190-197.

http://www.Sciencepub.net/nature

22. Muma, J.B.; Samui, K.L.; Siamudaala, V.M.; Oloya, J.; Matope, G.; Omer, M.K.; Munyeme, M.; Mubita, C. and Skjerve, E. (2006). Prevalence of antibodies to Brucella Spp. and individual risk factors of infections in traditional cattle, goats and sheep reared in Livestock-Wildlife interface areas of Zambia. Trop. Anim. Health Prod., 38:195-206.

23. Al-lzzi, S.A.; Al-Bassam, L.S. and AlDelaimi, A.K. (1985). A study on ovine brucellosis in Baghdad. Iraqi J. Vet. Med., 9(1): 19-27.

24. Al-Izzi, S.A. and Barhoom, S.S. (1988). Prevalence of brucellosis among sheep and goat in Baghdad, Iraq. Iraqi $J$. Vet. Sci.,1(2):108-115.

25. Selaisel, S.S. (1998). Assess the efficiency of serological tests used to detect brucellosis in animals. M.Sc. Thesis, College of Veterinary Medicine. Baghdad University.

26. Dhahir, S.H. (2002). Incidence of brucellosis in animals and man. Iraqi J. Vet. Med., 26(2):140-144.

27. Saleem, A.N.; Rhaymah, M.S. and Shamoo, G.N. (2004). Isolation and seroprevalence of ovine brucellosis. Iraqi $\mathrm{J}$. Vet. Sci., 18(1):31-38.

28. Al-Abdaly, I. B. (2005). Infection of brucellosis in Ninevah province with some biochemical aspects. PhD. Thesis College of Vet. Med. Mosul University.

29. Al-Hangawe, O.K.S. (2006). Comparative diagnosis study of brucellosis in sheep and goats in Ninevah province using ELISA and other serological test. MSc. Thesis, College of Veterinary Medicine. Mosul University. 
30. Al-Farwachi, M.I.; Al-Badrani, B.A. and Al-Nima, T.M. (2010). Detection of brucella antigen in the aborted ovine fetal stomach contents using a modified ELISA test. Iraq. J. Vet. Sci., 24(1):1-4.

31. Arslan, S.H.; Hassan, M.M.; Mohammed, N.A.; Al-Hussary, N.A. and Al-Obaidi, Q.T. (2011). Changes in some biochemical parameters accompanied with brucellosis in sheep. Iraqi J. Vet. Sci., 25(1): 107-110.

32. Blood, D.C.; Radostits, O.M. and Henderson, J.A. (1985). Veterinary Medicine. $6^{\text {th }}$ Ed., Bailliere Tindall, London, PP: 605-624.

33. Mustafa, H.A. (2006). Detection of Brucellosis in sheep using PCR with other serological test. MSc Thesis, College of Veterinary Medicine. Mosul University.

34. Mansour, R.S. (2000). Epidemiological and diagnostic study of brucellosis in Ninevah province. MSc Thesis, College of Veterinary Medicine. Mosul University.

35. Garin-Bastuji, B.B.; Blasco, J.M.; Grayon, M. and Verger, J.M. (1998). Brucella melitensis infection in sheep: present and future. Vet. Res., 29: 255-274.
36. Yesuf, M.; Alemu, S.; Temesgen, W.; Mazengiac, H. and Negussie, H. (2010). Seroprevalence of ovine brucellosis in South Wollo, North Eastern Ethiopia. American-Eurasian J. Agric. Environ. Sci., 9(3): 288-291.

37. Smith, R.D. (2006). Veterinary Clinical Epidemiology. Taylor and Francis Group, LLC. $3^{\text {rd }}$ Ed. PP: 33-50.

38. CDC (Center for Disease Control and Prevention). (2007). Brucellosis. http://www.cdc.gov/ncidod/dbmb/diseasein fo/brucellosis_t.htm .

39. Szulowski, K. and Pilaszek, J. (2000). Frequent exposure of mice to crude brucella abortus proteins. J. Vet. Med. Ser. B-Infect. Dis. Vet. Public Health, 47(9): 677-682.

40. Minas, A.; Stournara, A.; Minas, M.; Papaioannou, A.; Krikelis, V. and Tselepidis, S. (2005). Validation of fluorescence polarization assay (FPA) and comparison with other tests used for diagnosis of $B$. melitensis infection in sheep. Vet. Microbiol., 111: 211-222.

\section{الكشف عن اضداد البروسيلا في أغنام محافظة الاتبار باستعمال بعض الاختبارات المصلية \\ أحمد هلال كامل الطائي و اكرام عباس عبود السامر ائي

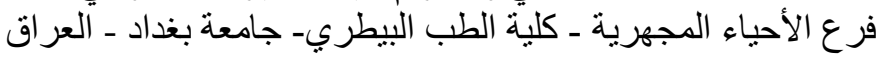

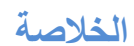

اجريت الدراسة للكثف عن اضداد البروسيلا في اغنام محافظة الانبار باستعمال بعض الاختبار اتلات المصلية (اختبار وردية

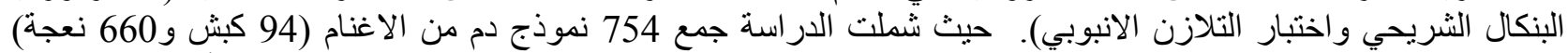

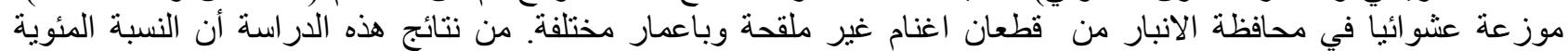

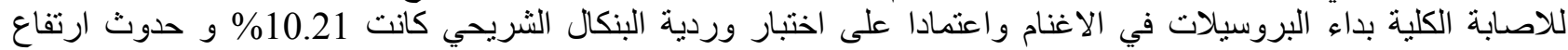

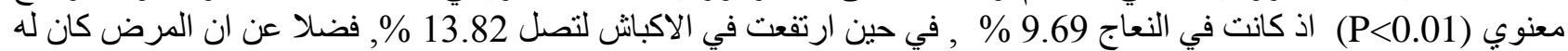

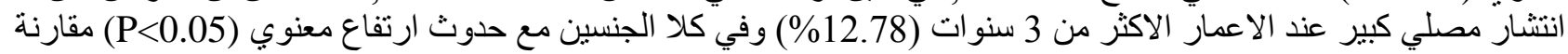

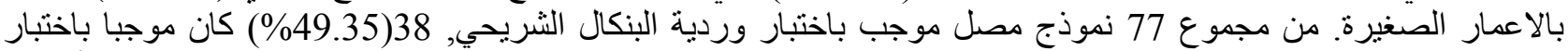

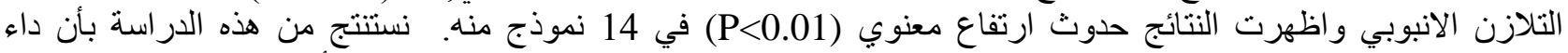

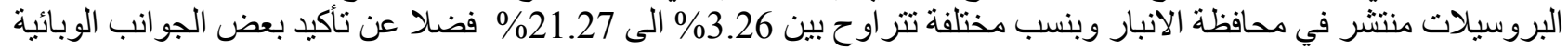

